J. Perinat. Med. 16 (1988)

\title{
Smoking during pregnancy and the perinatal cadmium burden
}

\author{
Radzisław Sikorski ${ }^{1}$, Tomasz Radomański ${ }^{1}$, Tomasz Paszkowski', and Józef Skoda ${ }^{2}$ \\ ${ }^{1}$ Clinic of Gynecology, Institute of Obstetrics and Gynecology, Academy of Medi- \\ cine, Lublin, Poland \\ ${ }^{2}$ Department of Pharmacology and Toxicology, Institute of Veterinary Research, \\ Puławy, Poland
}

\section{Introduction}

The influence of maternal smoking on fetal development has been investigated for almost 30 years $[1,3,4,6,9,15,16,18,24]$. Neonates born to smoking mothers were described as having "Fetal Tobacco Syndrome" (FTS) characterized mainly by a decreased birth weight [17]. Smoking is one of the important sources of cadmium contamination in humans $[2,8,14,19,20]$. One cigarette contains from 0.82 to $3.67 \mu \mathrm{g}$ of cadmium, about $10 \%$ of which is absorbed by the smoker. Several animal studies have shown a considerable embryofetotoxic activity of cadmium compounds $[5,19]$. The placenta seems to be one of the target organs for cadmium toxicity in humans [13]. Relatively high cadmium levels were found in human placental tissue $[5,13,22,23]$. It has been reported that a rapid and extensive accumulation of cadmium in the placenta leads to both the morphological and functional impairment of this organ $[10,13]$. Conflicting opinions exist concerning the placental transfer of cadmium in humans. Some authors state that the human placenta forms an effective biological barrier for cadmium [7, 10, 12] while others offer evidence suggesting that regardless of placental accumulation of this metal, cadmium penetrates the fetal compartment [11, 23]. The present investigation was undertaken in order to demonstrate whether smoking during pregnancy alters the perinatal cadmium burden and if so, what influence this may have on morphometric fetoplacental parameters.

\section{Material and methods}

The study population consisted of one hundred healthy parturients and 100 neonates born to them

\section{Curriculum vitae}

Prof. Radzislaw SikorSKI, M.D., was born in 1933 in Lublin, Poland. During 1951-1957, he studied medicine in the Academy of Medicine, Lublin. He specialized in $\mathrm{Ob}$ stetrics, Gynecology and Sexology. His present position is Head of the Gynecology Department and Dean of the Medical Faculty. His

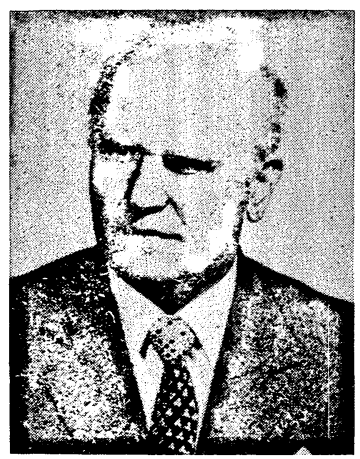
publications are directed toward prenatal toxicology, immunology of high risk pregnancy and female genital tract diseases, toxoplasmosis, social gynecology, and human sexuality.

between 37 and 42 weeks of pregnancy in the Institute of Obstetrics and Gynecology (State Clinical Hospital No 4) in Lublin, Poland. Thirtyseven women did not smoke during pregnancy (NSm) and the remaining 63 were current smokers (Sm). The median value of the number of cigarettes smoked daily by the examined gravidas was 6. For the purpose of subsequent analysis, the smoking group was divided into two subgroups: smokers who smoked 6 or less cigarettes per day ("Sm $\leq 6)$ "; $N=34$ ) and those who smoked more than 6 cigarettes a day ("Sm $>6$ "; $\mathrm{n}=29$ ). The characteristics of the subjects in the smoking groups are given in table I. None of the differences calculated for mean age, parity and the duration of pregnancy between the subgroups of women studied was statistically significant. 
Table I. The characteristics of the smoking groups

\begin{tabular}{lllr}
\hline Characteristic & $\mathrm{NSm}$ & $\mathrm{Sm} \leq 6$ & $\mathrm{Sm}>6$ \\
\hline Number of patients & 37 & 34 & \multicolumn{1}{l}{29} \\
Age (years) & $26.7 \pm 4.9^{*}$ & $26.1 \pm 5.1$ & $25.7 \pm 5.4$ \\
Parity & $1.8 \pm 0.9$ & $1.9 \pm 0.8$ & $1.7 \pm 0.8$ \\
Duration of pregnancy (weeks) & $39.5 \pm 0.3$ & $39.7 \pm 0.4$ & $39.5 \pm 0.3$ \\
\hline
\end{tabular}

NSm - nonsmokers

$\mathrm{Sm} \leq 6-$ smokers who smoked 6 or less cigarettes per day

$\mathrm{Sm}>6-$ smokers who smoked more than 6 cigarettes per day

$* \quad-$ arithmetic mean \pm standard deviation

Maternal and umbilical cord blood samples of approximately $10 \mathrm{ml}$ were collected as part of the routine procedures concerned with delivery. The cadmium concentration was measured in whole blood by means of atomic absorption spectrometry using the technique detailed elsewhere [26]. A total of 193 determinations were performed in 100 samples of maternal blood (MB) and 93 samples of umbilical cord blood (CB).

The distribution of both Cd-MB and Cd-CB was found to be skewed to the right, so that the statisti- cal analysis concerning levels of the metal was performed using the median test and the sign test [21]. The application of more "quantitative". statistics for the analysis of the laboratory data obtained may have included a statistical error since in a relatively high percentage the measured cadmium concentrations were within the range of "not detected" (less than $0.001 \mathrm{ppm}$ ). This was found in $51.0 \%$ of Cd-MB and $52.7 \%$ of Cd-CB. Morphometric birth parameters of the neonates were compared to the level of maternal smoking by means of the t-Student's test.

Table II. Comparison of selected feto-placental parameters in the studied subgroups (results of the Student's test)

\begin{tabular}{|c|c|c|c|c|c|c|}
\hline Parameter & $\begin{array}{l}\text { Sub- } \\
\text { group }\end{array}$ & $\mathbf{N}$ & $\mathrm{AM}$ & SD & $\begin{array}{l}\mathrm{CV} \\
(\%)\end{array}$ & $\begin{array}{l}\text { Significance of } \\
\text { difference* }\end{array}$ \\
\hline Birth weight(g) & $\begin{array}{l}\mathrm{NSm} \\
\mathrm{Sm} \leq 6 \\
\mathrm{Sm}>6\end{array}$ & $\begin{array}{l}37 \\
34 \\
29\end{array}$ & $\begin{array}{l}3465 \\
3396 \\
3033\end{array}$ & $\begin{array}{l}434 \\
392 \\
360\end{array}$ & $\begin{array}{l}65 \\
65 \\
63\end{array}$ & $\begin{array}{l}\mathrm{a} \\
\mathrm{a} \\
\mathrm{b}\end{array}$ \\
\hline Placental weight (g) & $\begin{array}{l}\mathrm{NSm} \\
\mathrm{Sm} \leq 6 \\
\mathrm{Sm}>6\end{array}$ & $\begin{array}{l}37 \\
34 \\
29\end{array}$ & $\begin{array}{l}651 \\
644 \\
615\end{array}$ & $\begin{array}{l}144 \\
144 \\
130\end{array}$ & $\begin{array}{l}21 \\
24 \\
23\end{array}$ & $\begin{array}{l}\mathrm{a} \\
\mathrm{a} \\
\mathrm{a}\end{array}$ \\
\hline Relative placental weight (\%) & $\begin{array}{l}\mathrm{NSm} \\
\mathrm{Sm} \leq 6 \\
\mathrm{Sm}>6\end{array}$ & $\begin{array}{l}37 \\
34 \\
29\end{array}$ & $\begin{array}{l}18.7 \\
18.8 \\
20.4\end{array}$ & $\begin{array}{l}3.2 \\
2.6 \\
4.0\end{array}$ & $\begin{array}{l}16.8 \\
13.7 \\
19.8\end{array}$ & $\begin{array}{l}\mathrm{a} \\
\mathrm{ab} \\
\mathrm{b}\end{array}$ \\
\hline Ponderal Index & $\begin{array}{l}\mathrm{NSm} \\
\mathrm{Sm} \leq 6 \\
\mathrm{Sm}>6\end{array}$ & $\begin{array}{l}37 \\
34 \\
29\end{array}$ & $\begin{array}{l}2.21 \\
2.15 \\
2.14\end{array}$ & $\begin{array}{l}0.23 \\
0.18 \\
0.23\end{array}$ & $\begin{array}{r}10.1 \\
8.4 \\
10.2\end{array}$ & $\begin{array}{l}\mathrm{a} \\
\mathrm{a} \\
\mathrm{a}\end{array}$ \\
\hline
\end{tabular}

$\mathrm{N} \quad-$ number of subject

AM $\quad$ - arithmetic mean

SD - standard deviation

$\mathrm{CV} \quad-$ coefficient of variation

* - means differ significantly (at $\mathrm{p}<0.05$ level of significance) is assigned by different letters (eg. "a" versus "b")

NSm - nonsmokers

$\mathrm{Sm} \leq 6-$ smokers who smoked 6 or less cigarettes per day

$\mathrm{Sm}>6$ - smokers who smoked more than 6 cigarettes per day 


\section{Results}

Table II presents selected fetoplacental parameters related to maternal smoking. The mean birth weight of the neonates born to nonsmoking mothers (3476 $\pm 434 \mathrm{~g})$, was significantly higher than that of the "Sm $>6$ " group $(3033 \pm 360 \mathrm{~g})$ $(p<0.05)$. The mean placental weight in the nonsmokers was higher than in both subgroups of smokers although these differences were not significant. However, when relative placental weight (placental weight to birth weight ratio $\times 100 \%$ ) was evaluated, the difference between the "Sm > 6" group $(20.4+4.0 \%)$ and the nonsmokers $(18.7+3.2 \%)$ appeared to be statistically significant $(\mathrm{p}<0.05)$. A slight, insignificant decrease in Roher's ponderal index (birth weight $(\mathrm{g}) /$ body length $(\mathrm{cm})^{3} \times 100$ ) was observed in the newborns of smoking mothers as compared to the infants of non-smokers.

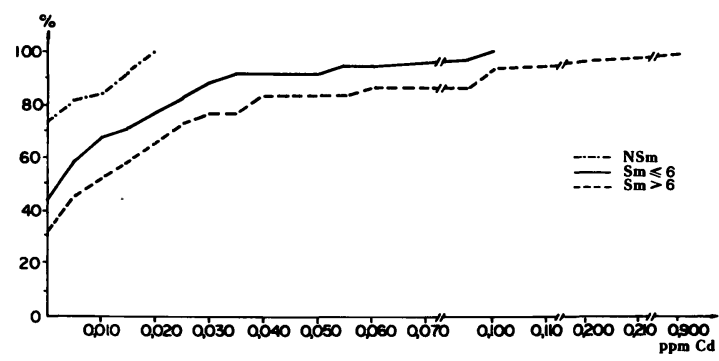

Figure 1. The frequency distribution pattern of cadmium values determined in maternal blood (MB); (NSm nonsmokers; $\mathrm{Sm} \leq 6-$ smokers who smoked 6 or less cigarettes per day; Sm $>6$ - smokers who smoked more than 6 cigarettes per day).
Figures 1 and 2 present the distribution of cadmium values determined in MB and CB. Detectable $\mathrm{Cd}$ concentrations were found in $27.0 \%$ of the blood samples obtained from nonsmoking mothers and in $32.4 \%$ of $\mathrm{CB}$ samples obtained from their neonates while in the "Sm" group detectable MB and CB cadmium levels were measured in $61.9 \%$ and $57.1 \%$ of samples respectively. These differences were statistically significant (for Cd-MB p < 0.001 and for Cd-CB p < 0.02) (table III). As shown in table IV, the average number of cigarettes smoked per day by the women had little effect on the measured metal levels. There was markedly significant correlation between MB and $\mathrm{CB}$ cadmium levels $\left(\chi^{2}=51.09 ; \mathrm{p}<0.001\right)$. In $19.4 \%$ of cases $\mathrm{Cd}-\mathrm{CB}$ exceeded the corresponding MB value. The direction of the transplacental gradient for cadmium as estimated by the sign test was statistically insignificant. None of the

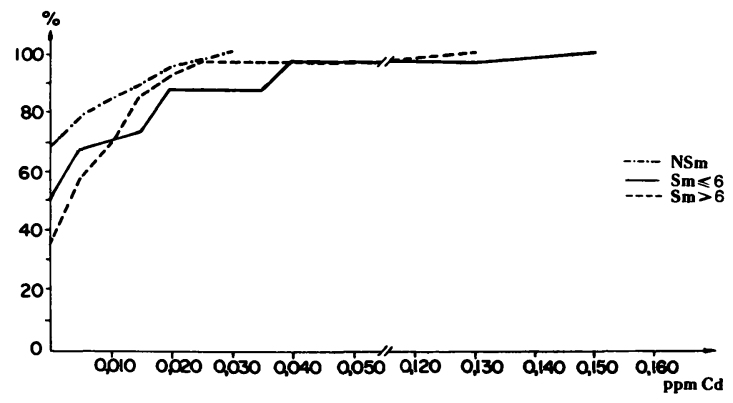

Figure 2. The frequency distribution pattern of cadmium values determined in umbilical cord blood (CB); (for abbreviations see figure 1).

Table III. Cadmium levels in maternal blood (MB) and umbilical cord blood (CB) in relation to maternal smoking during pregnancy

\begin{tabular}{lllll}
\hline Material & Group & $\mathrm{N}$ & \% of detectable Cd values & Significance of difference* \\
\hline \multirow{2}{*}{ MB } & NSm & 37 & 27.0 & $\chi^{2}=11.347 ; \mathrm{p}<0.001$ \\
& Sm & 63 & 61.9 & $\chi^{2}=5.457 ; \mathrm{p}<0.02$ \\
CB & NSm & 37 & 32.4 & \\
\hline
\end{tabular}

$\mathrm{N} \quad-$ number of subject

NSm - nonsmokers

Sm - smokers

* $\quad$ - chi-square test 
fetoplacental parameters studied (birth weight, placental weight, relative placental weight and ponderal index) was significantly associated with cadmium levels in MB and CB.

\section{Discussion}

The results obtained in this study confirm that the physical development of newborns with the FTS is retarded in comparison to the neonates of nonsmoking mothers $[4,17,24]$. Of the fetoplacental parameters analyzed, the decreased birth weight and higher relative placental weight were found to be associated both with maternal smoking per se as well as with the average number of cigarettes smoked per day. What deserves emphasis is that the relative placental weight appeared to be a more sensitive parameter for the diagnosis of the FTS than the absolute value of the placental weight. The Roher's ponderal index which is known to be a useful quantitative measure of the nutritional status at birth [25] did not differ significantly in the subgroups in our study, thus indicating that the growth retardation observed by us in newborns of smokers' could be considered as mild.

Compared to the extensive research efforts concerned with the toxo-clinical evaluation of other tobacco smoke compounds, relatively little interest has been focussed in perinatal medicine on the cadmium burden caused by maternal smoking [10, $11,12]$. The results obtained by us confirm that smoking during pregnancy leads to elevated cadmium concentration in both the mother and the fetus. The perinatal cadmium burden did not dif- fer significantly in the subgroups of smokers examine (table IV). The relatively low average number of cigarettes smoked daily by our patients may have contributed to this result. It would be of interest to examine these relationships in a population of heavy smokers (in our study group only 1 patient smoked more than 20 cigarettes per day). Of the possible sources of cadmium in the non-smoking mothers, dietary intake and atmospheric air pollution seem to be of major importance. Our findings with respect to cadmium levels on both sides of the placenta seem contrasting to the opinion that an effective placental barrier for cadmium exists which protects the unborn child from this toxic metal [7, 10, 12]. The excellent, positive correlation established in the present study between Cd-MB and Cd-CB ( $p<0.001)$ as well as the insignificant difference between cadmium levels measured in the mother and the fetus support the opinion that maternal exposure to cadmium poses a potential hazard for the developing fetus due to transplacental exposure to this highly toxic element.

The lack of significant association between blood cadmium and the analyzed birth parameters of the newborn indicates that the elevated cadmium burden in the smoking group did not directly affect the intrauterine growth of these neonates. Undoubtedly other associated with smoking factors such as the effects of nicotine, carbon monoxide and cyanide exposure, suppressed aryl hydrocarbon activity etc. play a role in the etiology of the FTS. The importance of chronic cadmium exposure as a factor resulting in the well described prenatal consequences of maternal smoking remains to be clarified.

Table IV. Cadmium levels in maternal blood (MB) and umbilical cord blood (CB) of the parturients who smoked during pregnancy in relation to number of cigarettes smoked per day

\begin{tabular}{lllll}
\hline Material & Group & $\mathrm{N}$ & \% of detectable CD values & Significance of difference* \\
\hline \multirow{2}{*}{ MB } & Sm $\leq 6$ & 34 & 41.2 & $\chi^{2}=1.229 ; \mathrm{p}<0.2$ \\
& $\mathrm{Sm}>6$ & 29 & 55.2 & \\
\hline \multirow{2}{*}{ CB } & $\mathrm{Sm} \leq 6$ & 30 & 43.3 & $\chi^{2}=1.149 ; \mathrm{p}<0.2$ \\
\hline
\end{tabular}

$\mathrm{N} \quad-$ number of subject

$\mathrm{Sm} \leq 6-$ smokers who smoked 6 or less cigarettes per day

$\mathrm{Sm}>6-$ smokers who smoked more than 6 cigarettes per day

$* \quad-$ chi-square test 


\section{Abstract}

The association between maternal smoking and both morphometric birth parameters and the perinatal cadmium burden were studied. The cadmium concentrations were measured by atomic absorption spectrometry in 100 samples of maternal whole blood (MB) and in 93 samples of umbilical cord blood (CB). In the group of nonsmokers, significantly higher birth weight and decreased relative placental weight were noted as compared to the group of smokers who smoked more than 6 cigarettes a day $(\mathrm{p}<0.05)$. In both maternal and cord blood samples, the measured $\mathrm{Cd}$ levels were found to be significantly higher in smokers than in the nonsmoking
\end{abstract}

subjects (for $\mathrm{MB}$ and $\mathrm{CB} \mathrm{p}<0.01$ and $\mathrm{p}<0.01$ respectively). The average number of cigarettes smoked daily by the women had little effect on the levels of the metal. The Cd-MB strongly correlated with the Cd-CB ( $\mathrm{p}<0.001$ ). The cadmium values determined in $\mathrm{MB}$ and CB did not significantly affect any of the studied fetoplacental parameters. The reported findings give support for placental permeability to cadmium in humans and confirm that smoking during pregnancy leads to elevated $\mathrm{Cd}$ concentrations in both the mother and the fetus.

Keywords: Cadmium, fetal tobacco syndrome, prenatal toxicology.

\section{Zusammenfassung}

Rauchen während der Schwangerschaft und perinatale Cadmium-Belastung

Untersucht wurde, ob Rauchen während der Schwangerschaft die perinatale Cadmium(Cd)-Belastung und morphometrische Parameter der Neugeborenen beeinflußt. Die Cadmium-Spiegel wurden mittels Atomabsorptionsspektrometrie in 100 mütterlichen Blutproben (MB) sowie 93 Proben aus dem Nabelschnurblut (CB, cord blood) bestimmt. Die Mütter wurden in 2 Gruppen aufgeteilt: Raucher $(n=63)$ und Nichtraucher $(n=37)$. Bei den Rauchern wurden 2 Untergruppen gebildet: Raucher mit $\leq 6$ Zigaretten pro Tag $(\mathrm{n}=34)$ und Raucher mit $>6$ Zigarettenpro Tag $(n=29)$. Das mittlere Geburtsgewicht der Kinder von Nichtraucherinnen lag signifikant über dem der Kinder von Müttern mit mehr als 6 Zigaretten pro Tag ( $p<0.05$, Tabelle II). In dieser Gruppe war das relative Plazentagewicht im Vergleich mit den Nichtrauchern erhöht $(p<0.05)$. Der Gewichtsindex von Neugeborenen rauchender Mütter zeigte einen geringen Abfall. Bei den Rauchern fanden sich meßbare Cd-Spiegel (oberhalb $0.001 \mathrm{mg} / \mathrm{kg}$ ) in $61.9 \%$ der MBProben und in $57.1 \%$ der CB-Proben, bei den Nichtrauchern waren es $27.0 \%$ bzw. $32.4 \%$ (Tabellen I und II). Die Unterschiede sind signifikant: $\mathrm{p}<0.001$ für Cadmium in $\mathrm{MB}$ und $\mathrm{p}<0.02$ für Cadmium in CB. Die Menge der pro Tag gerauchten Zigaretten hatte einen geringen Einfluß auf die Höhe des Spiegels. Cd-MB korrelierte streng mit Cd-CB ( $p<0.01$ ). Die CadmiumWerte in $\mathrm{MB}$ und $\mathrm{CB}$ hatten keinen signifikanten Einfluß auf die untersuchten fetoplazentaren Parameter. Unsere Ergebnisse bestätigen, daß Rauchen während der Schwangerschaft zu erhöhten Cadmiumwerten bei Mutter und Fet führt. Die menschliche Plazenta ist für Cadmium sicher permeabel. Die beim „fetalen Nikotin-Syndrom" beobachtete Wachstumsretardierung kann bei mäßigem Nikotingenuß nicht direkt auf eine gesteigerte transplazentare Cadmium-Aufnahme durch den Feten zurückgeführt werden.

Schlüsselwörter: Cadmium, fetales Nikotinsyndrom, pränatale Toxikologie.

\section{Résumé}

Tabagisme pendant la grossesse et charge périnatale en cadmium

Le but de cette étude était de déterminer si le tabagisme maternel contribue à la charge périnatale en cadmium et si oui, quelle influence celà peut-il avoir sur les paramètres morphométriques de croissance des nouveau-nés de mères tabagiques? On a mesuré les taux de cadmium par spectrométrie d'absorption atomique dans 100 échantillons de sang total maternal (MB) et dans 93 échatillons de sang du cordon ombilical (CB). Les parturientes explorées ont été divisée en 2 groupes suivant le tabagisme de la grossesse: les fumeuses ( $\mathrm{Sm} » ; n=63)$ et les non fumeuses ( $\mathrm{NSm} » ; \mathrm{n}=37$ ). En outre, 2 sousgroupes de fumeuses ont été réalisés: les fumeuses de 6 cigarettes ou moins par jour ( $" \mathrm{Sm} \leq 6 » ; \mathrm{n}=34$ ) et les fumeuses de plus de 6 cigarettes par jour ( $(\mathrm{Sm}>6 »$; $n=29)$. Le poids de naissance moyen des nouveauxnés de mères non fumeuses dépasse de façon significative celui du groupe « $\mathrm{Sm}>6$ » $(\mathrm{p}<0,05)$ (tableau II). On a observé une augmentation significative du poids placentaire relatif dans le groupe " $\mathrm{Sm}>6$ " en comparaison avec les non fumeuses $(p<0,05)$. Il a été noté une légère diminution de l'index pondéral chez les nouveauxnés de mères tabagiques. Ches les fumeuses, on a trouvé des taux détectables de Cd (au dessus de $0,001 \mathrm{mg} / \mathrm{kg}$ ) dans $61,9 \%$ des échantillons $\mathrm{MB}$ et dans $57,1 \%$ des échantillons CB alors que dans le groupe "NSm» les valeurs correspondantes étaient respectivement de 
$27,0 \%$ et de $32,4 \%$ (tableaux I et II). Les différences sont significative avec $\mathrm{p}<0,001(\mathrm{Cd}-\mathrm{MB})$ et $\mathrm{p}<0,02$ (Cd-CB). Le nombre moyen de cigarettes fumées chaque jour par les femmes enceintes étudiées n'a que peu d'effet sur les taux de cadmium. Le Cd-MB est fortement corrélé avec le Cd-CB $(p<0,001)$. Les valeurs de Cadmium déterminées dans $M B$ et $C B$ ne modifient pas de façon significative les paramètres fœto-placentaires étudiés quels qu'ils soient.
Les résultats de cette étude confirment que le tabagisme au cours de la grossesse entraîne une élévation des concentrations de $\mathrm{Cd}$ chez la mère et chez le fotus. Les données rapportées prouvent que le placenta est perméable au cadmium dans l'espèce humaine. Le retard de croissance intra-utérin observé dans le syndrome «du fœtus tabagique» ne semble pas être secondaire directement à l'élévation des entrées trans-placentaires de cadmium chez les fœtus de fumeuses modérées.

Mots-clés: Cadmium, syndrome de tabagisme fotal, toxicologie prénatale.

\section{References}

[1] BeCKeR RF, CR LITTLE, JE KING: Experimentál studies on nicotine absorption in rats during pregnancy. Am J Obstet Gynecol 100 (1968) 957

[2] Brockhaus A, I Freier, U Ewers, E Jermann, R DolGNER: Levels of cadmium and lead in blood in relation to smoking, sex, occupation and other factors in an adult population of the FRG. Int Arch Occup Environ Health 52 (1983) 167

[3] BUNCHER CR: Cigarette smoking and duration of pregnancy. Am J Obstet Gynecol 103 (1969) 942

[4] BUTLER NR, H Goldstein, EM Ross: Cigarette smoking in pregnancy: Its influence on birth weight and perinatal mortality. Br Med J 2 (1972) 127

[5] Clarkson TW, GF Nordberg, PR Sager: An overview of the reproductive and developmental toxicity of metals. In: Clarkson TW, GF NoRDBERG, PR SAGER: Reproductive and developmental toxicity of metals. Plenum Press, New York-London 1983

[6] Comstock GW, FE Lundin JR: Parental smoking and perinatal mortality. Am J Obstet Gynecol 98 (1967) 708

[7] Friberg L, T Kuellstrom, GF Nordberg, M PisCATOR: Cadmium. In: FrIBERG L, GF NORDBERG, VB Vouk: Handbook on the toxicology of metals. Elsevier North Holland Biomedical Press, Amsterdam - New York - Oxford 1979

[8] Gramsmick C, G Huel, T Morrau, H Sarmini: The combined effect of tobacco and alcohol consumption on the level of lead and cadmium in blood. Sci Total Environ 41 (1985) 207

[9] Herriot A, WZ Billewicz, FE HytTen: Cigarette smoking in pregnancy. Lancet 1 (1962) 771

[10] JeNDRYCZKo A, M DRozdZ, K MAgneR, J TOMAla: Zwiekszone stezenie kadmu w lozysku i moczu kobiet palacych papierosy. Gin Pol 56 (1985) 592

[11] KLINK F, JR JUNGBLUT, F OBERHEUSER, CP SIEGERS: Cadmium and lead concentrations in the amniotic fluid of pregnant smokers and non-smokers. Geburtshilfe Frauenheilkd 43 (1983) 695

[12] KuHERT PM, BR KuHNERT, SF BOtTOMS, P ERHARDT: Cadmium levels in maternal blood, fetal cord blood and placental tissues of pregnant women who smoke. Am J Obstet Gynecol 142 (1982) 1021
[13] LeVin AA, RK Miller, PA Di Sant'Agnese: Heavy metal alterations of placental function: a mechanism for the induction of fetal toxicity in cadmium. In: Clarkson TW, GF NORDBERG, PR SAGER: Reproductive and developmental toxicity of metals. Plenum Press, New York-London 1983

[14] Lewis GP, WJ Jusko, LL Coughlin, S Hortz: Contribution of cigarette smoking to cadmium accumulation in man. Lancet 1 (1972) 291

[15] LoNGo LD: The biological effect of carbon monoxide on the pregnant women, fetus and newborn infant. Am J Obstet Gynecol 129 (1977) 69

[16] Mochizuki M, T Maruo, K Masuko, T Ohtsu: Effects of smoking on fetoplacental-maternal system during pregnancy. Am J Obstet Gynecol 149 (1984) 413

[17] Nieburg P, JS Marks, NM Mclaren, PL ReMINGTON: The fetal tobacco syndrome. J Am Med Assoc 253 (1985) 2998

[18] Nilsen ST, N Sagen, H Chankim, P Bergsjo: Smoking, hemoglobin levels and birth weights in normal pregnancies. Am J Obstet Gynecol 148 (1984) 752

[19] Ferry HM, GS THIND, EF PERry: The biology of cadmium. Med Clin North Am 60 (1976) 759

[20] Sharma RP, T KJellstrom, JM McKenZIE: Cadmium in Blood and urine among smokers and nonsmokers with high cadmium intake via food. Toxicology 29 (1983) 163

[21] SIEGEL S: Nonparametric statistics for the behavioral sciences. Mc Graw-Hill Book Company Inc., New York - Toronto - London 1956

[22] Takacs VS, L Borkai, A Tatar, A Hardanyi: Kupfer, Zinc, Blei und Kadmium in der Plazenta. Zentralbl Gynakol 106 (1984) 1357

[23] Tsuchiya H, K Mitani, K Kodama, T Nakata: Placental transfer of heavy metals in normal pregnant Japanese women. Arch Environ Health 39 (1984) 11

[24] VAN DER VeLDE WJ, PE TREFFERS: Smoking in pregnancy: The influence on percentile birth weight, mean birth weight, placental weight, menstrual age, perinatal mortality and maternal diastolic blood pressure. Gynecol Obstet Invest 19 (1985) 57 
[25] WALTHER FJ, LHJ RAMAEKERs: The ponderal index as a measure of the nutritional status at birth and its relation to some aspects of neonatal morbidity. J Perinat Med 10 (1982) 42
[26] Yeager DW, J CholaK, EW Henderson: Determination of lead in biological and related material by atomic absorption spectrophotometry. Environ Sci Technol 5 (1971) 1020

Received May 15, 1987. Revised September 29, 1987. Accepted October 29, 1987.

Prof. Radzisław Sikorski

Clinic of Gynecology, I. O. G., A. M.

ul. Jaczewskiego 8

20-090 Lublin, Poland 